\section{The natural history of HCV in a cohort of haemophilic patients infected between 1961 and 1985}

T T Yee, A Griffioen, C A Sabin, G Dusheiko, C A Lee
Haemophilia Centre and Haemostasis Unit, Royal Free Hospital,

London, UK

T T Yee

A Griffioen

C A Lee

\section{Department of} Population Sciences and Primary Care, Royal Free and University College Medical School, University College, London, UK

C A Sabin

Department of Medicine, Royal Free and University College Medical School, University College, London, UK G Dusheiko

Correspondence to: Professor Christine Lee, Haemophilia Centre and Haemostasis Unit, Royal Free Hospital, Pond Street, London NW3 2QG, UK. Christine.Lee@rfh.nthames. nhs.uk

Accepted for publication 22 June 2000

\begin{abstract}
Aim-This study describes the long term follow up of haemophilic patients infected with hepatitis C virus (HCV) between 1961 and 1985.

Methods-Clinical and treatment records from 310 patients with inherited coagulation disorders treated with blood product before 1985 were reviewed. Standard survival analysis methods were used to model progression to liver failure and death.

Results-A total of 298/305 (98\%) patients tested were anti-HCV positive. Twenty seven $(9 \%)$ individuals consistently HCV polymerise chain reaction negative were considered to have cleared the virus. By 1 September 1999, 223/310 (72\%) were alive, $26(8 \%)$ had died a liver related death, and $61(20 \%)$ had died from other, predominantly human immunodeficiency virus (HIV) related, causes. Kaplan-Meier progression rates to death from any cause and liver related deaths 25 years after exposure to $\mathrm{HCV}$ were $47 \%$ (95\% confidence intervals (CI) 34-60) and 19\% (95\% CI 10-27), respectively. After 13.3 years from 1985 , by which time all patients had seroconverted to $\mathrm{HIV}$, progression rates to death from any cause and liver related deaths were, respectively, $8 \%$ (95\% CI 4-13) and 3\% (95\% CI 0.4-6) for those HIV negative, and $57 \%$ (95\% CI 48-66) and $21 \%$ (95\% CI 13-31) for those HIV positive $(p=0.0001)$. Using Cox proportional hazard models, the adjusted relative hazard of death for individuals coinfected with HIV compared with those infected with HCV alone was 19.47 (95\% CI 9.22-41.10), 0.99 (95\% CI 0.39-2.53), 3.47 (95\% CI 1.408.63), and 9.74 (95\% CI 3.91-24.26) for the age groups at infection 10-19 years, 20-29 years, and $>30$ years, respectively, compared with the age group $<10$ years. The adjusted relative hazard for genotype 1 compared with other genotypes was 2.7 (95\% CI 1.36-5.15)
\end{abstract}

Conclusions-While 25 year follow up of 310 haemophilic patients has shown the potentially lethal combination of HIV and HCV coinfection, HCV singly infected individuals show slow progression of liver disease.

(Gut 2000;47:845-851)

Keywords: hepatitis C virus; human immunodeficiency virus; haemophilia
A recent WHO report has underlined the importance of hepatitis $\mathrm{C}$ virus (HCV) as an emerging disease in public health programmes because of the significant morbidity and mortality caused in most parts of the world. Therefore, observation of long term infection is intrinsic to the successful management of an estimated 170 million individuals who are infected with HCV worldwide.

It is now firmly established that there is an emerging risk of morbidity and mortality from liver disease and primary liver cancer due to $\mathrm{HCV}$ among haemophilic patients in the UK. ${ }^{2}$ We have been monitoring a subpopulation of these patients, a total of 310 individuals with inherited bleeding disorders who were infected with $\mathrm{HCV}$, from the time of first exposure to blood products. In almost all cases, first exposure was the date of infection of $\mathrm{HCV}$ before the introduction of virucidal treatment in $1985 .^{3}$

We last reported on this cohort in $1993,{ }^{4}$ and we have extended our observation of the natural history of this infection to 1999 . This represents two decades of HCV infection for most patients. We have included detailed individual patient observations, including date of infection, HCV viral load, and genotype, as well as cause of death and influence of treatment. Although the natural history of $\mathrm{HCV}$ infection is different in some respects in this patient population compared with other risk groups, the study has the advantage of the knowledge of duration of infection and of long term follow up at a single centre in London, UK.

\section{Methods}

FOLLOW UP

The Royal Free Hospital Haemophilia Centre was established in 1964 and therefore it was possible to review the clinical and treatment records of all patients from this time until 1 September 1999. A computerised database was introduced in 1980. Over this period, patients with severe haemophilia (factor $<2$ $\mathrm{U} / \mathrm{dl}$ ) were seen six monthly and those with other inherited clotting deficiencies annually. From 1985 onwards, human immunodeficiency virus (HIV) seropositive patients were seen at least three monthly. Assessment included medical history, review of home and inpatient treatment records, physical examina-

Abbreviations used in this paper: $\mathrm{HCV}$, hepatitis $\mathrm{C}$ virus; HIV, human immunodeficiency virus; PCR, polymerase chain reaction; HBsAg, hepatitis B surface antigen; HCC, hepatocellular carcinoma. 
tion, and standard blood tests. From 1979, a serum sample was taken at each clinic visit and stored at $-40^{\circ} \mathrm{C}$.

The first large pool clotting factor concentrates were used to treat factor IX deficiency in 1961 and single donor pool cryoprecipitate was used from 1966 to treat factor VIII deficiency. ${ }^{5}$ There was a gradual introduction of large pool factor VIII concentrate from 1976. From 1985, all large pool clotting factor VIII and IX concentrates used in the centre were treated with virucidal processes. Individuals with von Willebrand's disorder were treated with cryoprecipitate or desmopressin before 1985. Patients with factor XI deficiency were treated with fresh frozen plasma until a heated large pool clotting factor concentrate became available in $1990 .^{6}$

A total of 76 patients received antiviral therapy for HCV in 106 treatment episodes. Two patients received alpha interferon from 1987 and have previously been reported. ${ }^{7}$ Alpha interferon alone was used in 53 treatment episodes, including five patients who were treated twice and one who received three courses of therapy. ${ }^{8}$ We participated in a double blind controlled trial of ribavirin versus placebo in 12 patients in 1992 and subsequently continued open label therapy in two individuals. ${ }^{9}$ Combination therapy with ribavirin and alpha interferon was commenced in 1996: of a total of $37 \mathrm{HIV}$ negative patients treated, 33 have completed the course. ${ }^{10}$

STATISTICAL METHODS

Comparisons between groups were made using the chi square test or Fisher's exact test for categorical variables, and the Mann-Whitney U test for continuous variables because of the expected non-normality of these variables. Standard survival analysis methods were used to model progression to death. Person-years at risk were calculated using the date of first exposure to unsterilised concentrate until death or 1 September 1999. For those patients lost to follow up (49 (16\%)) the end point was taken as the date when the patient was last reviewed at the centre; information on last attendance at another centre was used where available. Kaplan-Meier progression rates and $95 \%$ confidence intervals $(\mathrm{CI})$ were calculated from 1985 until the censoring date for analyses relating to HIV infection. To visually illustrate the impact of HIV infection on survival, Kaplan-Meier plots were also drawn using a baseline date of 12 January 1985 by which time HIV positive patients had seroconverted. ${ }^{11} \mathrm{Cox}$ proportional hazard models were used to compare survival between groups. HCV genotype and age at first exposure to concentrates were used to group patients: $<10$ years, $10-19$ years, $20-29$ years, and $>30$ years of age were taken as fixed covariates at baseline. Seroconversion to HIV and time of first anti-HCV therapy were considered as time updated covariates, taking the value 0 prior to the time of seroconversion/ starting therapy and 1 thereafter. The first exposure date was known for 228 (74\%) patients. For those patients for whom the exposure date was not known, the median exposure date, July 1977, was used. Analyses were repeated, including only those individuals with a known date of infection. Results of these analyses were unchanged and therefore not included.

VIROLOGY AND IMMUNOLOGY

Fresh or serum stored from 1979 from patients who had received any blood product therapy was tested for antibodies to $\mathrm{HCV}$ using a second generation enzyme immunoassay EIA (Ortho Diagnostics, Amersham, UK). RIBA-2 was used as a confirmatory test in those who appeared to have cleared HCV infection naturally and were polymerase chain reaction (PCR) negative. Confirmation of ongoing $\mathrm{HCV}$ infection was made by detection of $\mathrm{HCV}$ viraemia either by qualitative reverse transcriptase PCR (Amplicor HCV test, Roche, Lewes, UK) or branched DNA (bDNA) assays. HCV genotyping was performed by extracting serum RNA from which HCV RNA was detected by reverse transcription and nested PCR using primers derived from the 5' non-coding region of the HCV genome. Genotype was determined from the pattern of DNA fragmentation after digestion of the PCR product with the two enzyme pairs Mva 1+Hinf and Hae III+Rsa 1. Hepatitis B surface antigen (HBsAg) was tested by EIA (Murex Diagnostics, Abbott, Maidenhead, UK). Antibodies to HIV were tested by EIA (Wellcozyme, Murex Diagnostics, Abbott, Maidenhead, UK) and confirmed by gelatin particle agglutination (Mast Diagnostics, Liverpool, UK and Abbott, Maidenhead, UK).

\section{Results}

SEROLOGICAL AND VIRAL TESTING FOR HCV Of the 310 patients who had been treated with non-virucidally treated blood products, 305 were tested for HCV and five patients (who had also been treated with large pool nonvirucidally treated clotting factor concentrate) had died before HCV antibody tests became available and there were no stored serum samples available for testing. A total of 298/305 (98\%) patients were anti-HCV positive and the remaining seven $(2 \%)$ were anti-HCV negative. Of the 200 patients in whom it was possible to determine HCV viraemia, 27/200 (14\%) were consistently HCV PCR negative in recent and archived specimens. These 27 individuals were thought to have cleared the virus and were studied in more detail.

\section{EXPOSURE TO HCV AND HIV}

Of the 310 patients who were exposed to a high HCV risk blood product, the source of infection was thought to be large pool nonvirucidally treated concentrate in 287 (93\%), and of these the date of exposure was known in 216 (75\%); median date was July 1977 (range 1961-1985). One patient was treated with factor IX concentrate as early as May 1961 in Oxford. Of the 22 patients who became infected from cryoprecipitate, the date of infection was known in 11, including one patient who was a carrier of haemophilia A and developed fulminant hepatitis C following 
Table 1 Demographics of the cohort of 310 patients

\begin{tabular}{|c|c|c|c|c|c|c|c|c|}
\hline & Alive & & Liver related d & aths & Other deaths & & Total & \\
\hline Total & $223(100)$ & & $26(100)$ & & $61(100)$ & & $310(100)$ & \\
\hline \multicolumn{9}{|c|}{ Coagulation disorder } \\
\hline Haemophilia A & $147(66)$ & & $22(85)$ & & $58(95)$ & & $227(73)$ & \\
\hline Haemophilia B & $44(20)$ & & $3(12)$ & & $2(3)$ & & $49(16)$ & \\
\hline VWD & $23(10)$ & & $1(4)$ & & $1(2)$ & & $25(8)$ & \\
\hline Other & $9(4)$ & & & & & & $9(3)$ & \\
\hline \multicolumn{9}{|c|}{ Age (y) at $\mathrm{HCV}$ infection } \\
\hline Median & 15.3 & & 27.2 & & 23.3 & & 17.4 & \\
\hline Range & $(0.01-61.3)$ & & $(6.8-62.8)$ & & $(2.0-76.8)$ & & $(0.01-76.8)$ & \\
\hline \multicolumn{9}{|l|}{ HIV } \\
\hline HIV positive & $54(24)$ & & $20(77)$ & & $51(84)$ & & $125(40)$ & \\
\hline \multicolumn{9}{|l|}{ HCV genotype } \\
\hline Total tested & $159(71)$ & $(100)$ & $22(85)$ & (100) & $32(52)$ & (100) & $213(67)$ & (100) \\
\hline 1 & 94 & (59) & 19 & (86) & 22 & (69) & 135 & (63) \\
\hline 2 & 23 & (15) & 3 & (14) & 3 & (9) & 29 & (14) \\
\hline 3 & 34 & (21) & & & 5 & (16) & 39 & (18) \\
\hline 4 & 2 & (1) & & & 2 & (6) & 4 & (2) \\
\hline 5 & 2 & (1) & & & & & 2 & (1) \\
\hline Mixed & 4 & (3) & & & & & 4 & (2) \\
\hline \multicolumn{9}{|l|}{$\mathrm{HCV}$ viraemia } \\
\hline Total tested & $189(83)$ & $(100)$ & $7(27)$ & $(100)$ & $4(7)$ & $(100)$ & $200(65)$ & $(100)$ \\
\hline Positive & 133 & $(70)$ & 7 & $(100)$ & 3 & (75) & 143 & (72) \\
\hline \multirow{2}{*}{\multicolumn{9}{|c|}{$\begin{array}{l}\text { Last measured HCV viral } \\
\text { load } \times 10^{6} \text { genome eq } / \mathrm{ml}\end{array}$}} \\
\hline & & & & & & & & \\
\hline Total tested & $150(67)$ & & $7(27)$ & & $3(5)$ & & $160(49)$ & \\
\hline Median & 8.1 & & 19.1 & & & & 8.3 & \\
\hline Range & $(<0.2-126)$ & & $(1.3-41.4)$ & & $(1.3-16)$ & & $(<0.2-126)$ & \\
\hline
\end{tabular}

Total cohort ( ) percentage; subpopulation () percentage.

VWD, von Willebrand's disease.

treatment with cryoprecipitate in $1981 .^{12} \mathrm{~A}$ patient who was treated with several hundred donor units of cryoprecipitate at another hospital in 1990 was the only patient infected after 1985. Six patients, of whom two had died, were HBsAg positive. Previous study of this cohort of patients using archival specimens showed that patients were infected with HIV between 1979 and 1985 (median seroconversion date 1983). ${ }^{11}$

DEMOGRAPHICS (TABLE 1)

Of the total 310 patients, $223(72 \%)$ were alive on 1 September 1999, $26(8 \%)$ had died of liver related diseases, and $61(20 \%)$ had died from other causes. The inherited coagulation disorders were haemophilia A, factor VIII deficiency $(227(73 \%))$; haemophilia B, factor IX deficiency (49 (16\%)); von Willebrand's disease $(25(8 \%))$; and other deficiencies (nine $(3 \%))$. This distribution reflects the relative prevalence of these disorders in the haemophilic population. There were a higher number of deaths within the haemophilia A group ( $85 \%$ of 26 liver related deaths and $95 \%$ of 61 deaths not caused by liver disease). Of the total 87 deaths, 80 patients had haemophilia A, five haemophilia B, and two von Willebrand's disease. Of the total population of 310,125 (40\%) were infected with HIV and of these 54 were alive, 20 had died from a liver associated disease, and 51 had died of other predominantly HIV related causes. HCV genotyping was performed in 213/310 (69\%) patients: 135 (63\%) were type $1,29(14 \%)$ type $2,39(18 \%)$ type 3 , and $10(5 \%)$ other genotypes. Of the $189(83 \%)$ living patients who were tested for $\mathrm{HCV}$ viraemia, $133(70 \%)$ were positive. Of the 57 patients who were PCR negative for HCV, 27 (9\%) were thought to have cleared the virus. All seven individuals who died of liver related diseases were HCV RNA positive. The $\mathrm{HCV}$ viral load in serum was higher in patients who had died from liver related disorders (median $19.1 \times 10^{6}$ ) compared with $8.1 \times 10^{6}$ genome eq $/ \mathrm{ml}$ in those still alive $(\mathrm{p}=0.16)$.

KAPLAN-MEIER ANALYSES

Progression rates to death from any cause and deaths related to liver disease 25 years after exposure to HCV were $47 \%$ (95\% CI 34-60) and $19 \%$ (95\% CI 10-27), respectively (fig 1). Patients were infected with HIV during the years 1979-1985, by which time virucidal treatment of large pool clotting factor concentrates was in use. Therefore, in order to show the effect of HIV on the progression of HCV related liver disease, Kaplan-Meier analyses were calculated from 1985, by which time all patients would have seroconverted to HIV. Thus over a 13.3 year interval from 1985, progression to death from all causes was $8 \%(95 \%$ CI 4-13) and 57\% (95\% CI 48-66) for those HIV negative and positive, respectively ( $\mathrm{p}=0.0001$; fig $2 \mathrm{~A})$; progression to death related to liver disease was 3\% (95\% CI $0.4-6)$ and $21 \%$ (95\% CI 13-31) for those HIV negative and positive, respectively $(\mathrm{p}=0.0001$; fig 2B).

COX PROPORTIONAL HAZARDS MODELS

The influence of HCV genotype, HIV coinfection, age at infection, and time of first anti-HCV therapy were examined using Cox

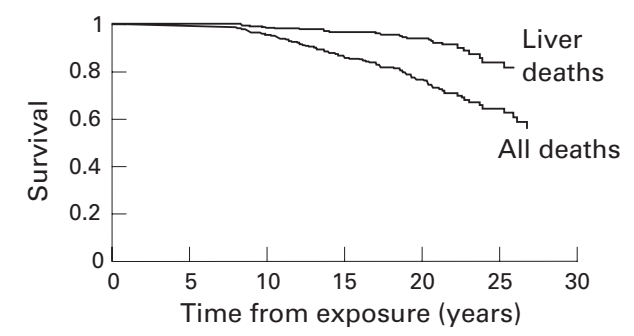

$\begin{array}{lllllll}\text { No. } & 310 & 307 & 291 & 246 & 162 & 41\end{array}$

at risk

Figure 1 Kaplan-Meier progression rates to death from any cause and deaths related to liver disease, yearly after exposure to hepatitis $C$ virus. 


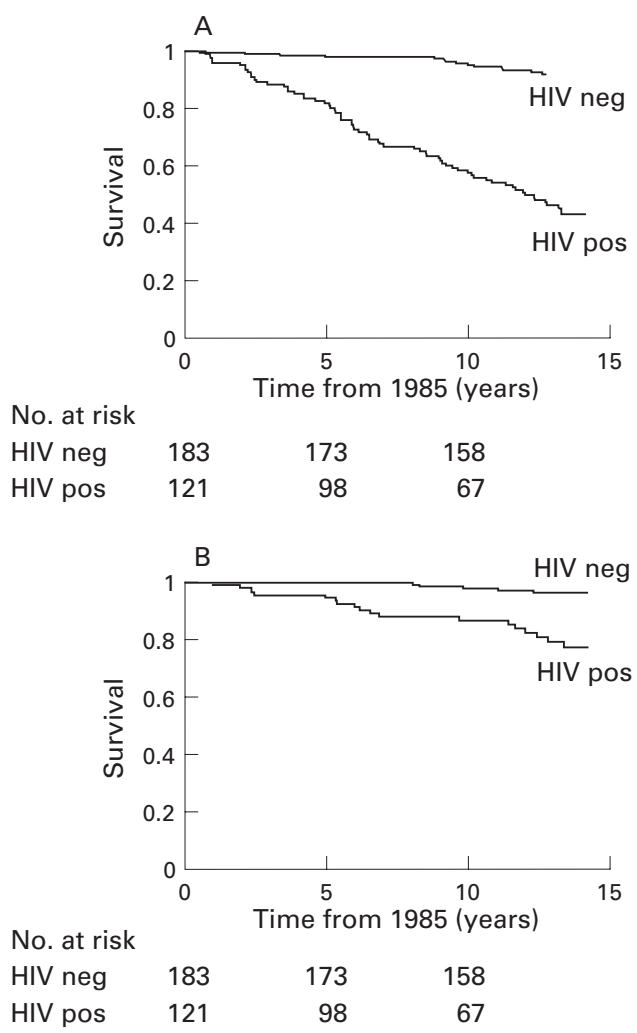

Figure 2 (A) Kaplan-Meier progression rate to death from any cause from 1985 in human immunodeficiency virus (HIV) positive and negative patients. (B) Kaplan-Meier progression rate to liver related death from 1985 in HIV positive and negative patients.

proportional hazards models (table 2). The relative hazards $(95 \% \mathrm{CI})$ associated with progression to "all" and "liver related" deaths, both unadjusted and adjusted, were calculated. In a multivariate analysis the relative hazard of dying for individuals coinfected with HIV compared with those infected with $\mathrm{HCV}$ alone was 19.47 (95\% CI 9.22-41.10) after adjusting for age at infection and genotype. The adjusted relative hazard was 0.99 (95\% CI 0.39-2.53), 3.47 (95\% CI 1.40-8.63), and 9.74 (CI 3.9124.26) for the age groups at infection 10-19 years, 20-29 years, and $>30$ years, respectively, compared with the age group $<10$ years. The adjusted relative hazard for genotype 1 com- pared with other genotypes was 2.65 (95\% CI 1.36-5.15).

The relative hazard of liver related death, adjusted for age and genotype, for those coinfected with HIV compared with those infected with HCV alone was 17.51 (95\% CI 5.82-52.72). The adjusted relative hazard for genotype 1 compared with other genotypes was 7.78 (95\% CI 1.96-30.83). After adjusting for genotype and HIV coinfection, the relative hazards of liver related death were $1.66(95 \%$ CI 0.17-16.12), 16.04 (95\% CI 1.96-131.45), and 45.93 (95\% CI 5.47-385.91) for the age groups at infection 10-19 years, 20-29 years, and $>30$ years, respectively, compared with the age group $<10$ years. This clearly shows that the relative hazard associated with progression to death increases with age at exposure to HCV. Thus coinfection with HIV, age at infection, and genotype $1 \mathrm{HCV}$ were the major determinants of death. (As only six of the total 310 population were $\mathrm{HBsAg}$ positive, this was not taken into account in the hazards analysis.)

\section{PATIENTS WHO DIED AND HAD LIVER RELATED} PATHOLOGY

Twenty six patients had died and had liver related pathology at the time of death. All were male with a median duration of $\mathrm{HCV}$ infection of 17 years (range 8-25). Median age at death was 47 years (range 23-76). Two patients were HBsAg positive. Of the 26 patients, $20(77 \%)$ were coinfected with HIV and five (19\%) were known to have increased alcohol consumption, defined as greater than $80 \mathrm{~g}$ of alcohol/day. Of the six HIV negative patients, four had increased alcohol intake and one died from haemorrhage following liver biopsy performed in $1981 .{ }^{13}$ One co-infected patient died from fulminating liver failure from drug related hepatotoxicity. ${ }^{14}$ HIV infection and/or alcohol were cofactors in 23/26 (88\%) deaths. Seventeen patients died in hepatic failure, seven had acquired immunodeficiency syndrome, and three had presumed hepatocellular carcinoma (HCC). A liver biopsy during life had shown cirrhosis in three patients and drug related hepatitis in one; at post mortem there were a further eight patients with cirrhosis (total $11 / 25,44 \%$ ) and two with chronic hepatitis.

Table 2 Relative hazards (95\% CI) associated with progression to death

\begin{tabular}{|c|c|c|c|c|c|c|}
\hline Variable & $\begin{array}{l}\text { All deaths } \\
\text { Relative } \\
\text { hazard }\end{array}$ & $95 \% C I$ & $p$ & $\begin{array}{l}\text { Liver relo } \\
\text { Relative } \\
\text { hazard }\end{array}$ & $\begin{array}{l}\text { deaths } \\
95 \% \text { CI }\end{array}$ & $p$ \\
\hline \multicolumn{7}{|l|}{ (a) Unadjusted } \\
\hline Genotype 1 & 1.91 & $(1.03-3.57)$ & 0.04 & 3.92 & $(1.16-13.24)$ & 0.03 \\
\hline HIV seroconversion $\star$ & 7.60 & $(4.63-12.37)$ & 0.0001 & 4.64 & $(2.06-10.45)$ & 0.0002 \\
\hline \multicolumn{7}{|l|}{ Age (y) at HCV infection } \\
\hline$<10$ & 1.0 & & & & & \\
\hline $10-19$ & 2.08 & $(0.96-4.51)$ & 0.06 & 1.59 & $(0.29-8.7)$ & 0.06 \\
\hline $20-29$ & 2.80 & $(1.25-6.29)$ & 0.01 & 5.95 & $(1.26-28.04)$ & 0.02 \\
\hline$>30$ & 6.43 & $(3.11-13.30)$ & 0.0001 & 9.18 & $(2.05-41.06)$ & 0.004 \\
\hline Time of first anti-HCV therapy ${ }^{\star}$ & 0.71 & $(0.32-1.58)$ & 0.41 & 1.22 & $(0.40-3.74)$ & 0.72 \\
\hline \multicolumn{7}{|l|}{ (b) Adjusted } \\
\hline HIV seroconversion ${ }^{\star}$ & 19.47 & $(9.22-41.10)$ & 0.0001 & 17.51 & $(5.82-52.72)$ & 0.0001 \\
\hline \multicolumn{7}{|l|}{ Age (y) at HCV infection } \\
\hline$<10$ & 1.0 & & & 1.0 & & \\
\hline $10-19$ & 0.99 & $(0.39-2.53)$ & 0.987 & 1.66 & $(0.17-16.12)$ & 0.66 \\
\hline $20-29$ & 3.47 & $(1.40-8.63$ & 0.007 & 16.04 & $(1.96-131.45)$ & 0.01 \\
\hline$>30$ & 9.74 & $(3.91-24.26)$ & 0.0001 & 45.93 & $(5.47-385.91)$ & 0.0004 \\
\hline Genotype 1 & 2.65 & $(1.36-5.15)$ & 0.004 & 7.78 & $(1.96-30.83)$ & 0.004 \\
\hline
\end{tabular}

*Time dependent variables. 
NATURAL IMMUNITY

Of the 27 patients who were thought to have cleared the virus, 26 were male and one was female. Seven had severe haemophilia A (factor VIII $<2 \mathrm{U} / \mathrm{dl}$ ), seven had moderate/mild haemophilia A (factor VIII $>2 \mathrm{U} / \mathrm{dl}$ ), four severe haemophilia B (factor IX $<2 \mathrm{U} / \mathrm{dl}$ ), four mild/moderate haemophilia B (factor IX $>2$ $\mathrm{U} / \mathrm{dl}$ ), one was a carrier of haemophilia $\mathrm{A}$, and four had von Willebrand's disease. Three (all with severe haemophilia A) of the 27 patients were coinfected with HIV. Three patients had been treated only with cryoprecipitate. The remaining 24 had been treated with both cryoprecipitate and large pool clotting factor concentrate of both US and UK donor pool origin. Age at first exposure was median 9 years (range 3 months to 56 years). In 25 patients, normal liver serum aminotransferases were recorded at least once a year for a median follow up period of 15 years. One of two patients who recorded abnormal liver aminotransferases had increased alcohol intake; the other received antiretroviral therapy for HIV and this was thought to be the cause of the abnormalities. Serial measurements of $\mathrm{HCV}$ viraemia were performed on a median of 5 (range 3-10) archived and recent (within the previous eight months) serum samples in these 27 patients. HCV RNA was undetectable in all 154 serum samples tested.

EFFECT OF TREATMENT

In total, $15 / 76(20 \%)$ patients became HCV RNA negative by PCR following treatment. Anti-HCV therapy was not shown to influence progression to all or liver related deaths (table 2)

\section{Discussion}

This detailed follow up of 310 haemophilic patients has shown the lethal combination of HCV and HIV coinfection, with $47 \%$ progression to death from any cause and $19 \%$ to liver related death after 25 years. However, for those $\mathrm{HCV}$ positive individuals without HIV infection, we have shown that hepatitis $\mathrm{C}$ is a very slowly progressive disorder with a $3 \%$ progression rate to a liver related death from the time of HIV infection in 1985.

Severe liver disease has been reported in non-haemophilic immunosuppressed patients infected with HCV who are receiving corticosteroids and other immunosuppressive agents. This is unexplained but could be related to a cytopathic effect of $\mathrm{HCV}^{15}$ A similar adverse effect on the natural progression of $\mathrm{HCV}$ would be expected in patients with HIV infection, and this has previously been shown in homosexual and haemophilic patients, and intravenous drug users. ${ }^{16-18} \mathrm{HCV}$ viral loads have been reported to be higher in coinfected individuals in previous studies in this cohort ${ }^{19}$ and by others. ${ }^{20}$ The viral load or level of circulating HCV RNA in serum is a reflection of both the rate of viral replication and the rate of viral clearance in the infected host. $\mathrm{HCV}$, an RNA virus, has a high mutation rate which leads to generation of quasispecies. ${ }^{21}$ In untreated patients with chronic $\mathrm{HCV}$ infection the viral load is relatively stable. ${ }^{22}$ Viral loads found in our patients were relatively high, particularly in those coinfected with HIV, and presumably this reflects the inability to contain the virus in the face of immunosuppression.

We found that HCV genotype 1 was associated with an increased relative hazard of progressing to death from any cause and specifically to death from liver disease, even when this was adjusted for HIV infection and age at infection. Contradictory results have been reported with respect to the influence of genotype on progression. ${ }^{23}$ Genotype 1 was associated with more severe disease in 4176 HCV positive Japanese patients, ${ }^{24}$ and in a further Japanese study in 140 patients, genotype 1 was associated with deterioration of liver biopsy. ${ }^{25}$ Dusheiko et al also found more severe disease in type 1 compared with type $2 \mathrm{HCV}$ infection. ${ }^{26}$ However, a recent study from Italy showed no role for genotype in determining disease outcome. ${ }^{27}$ We and others have also demonstrated the influence of genotype 1 HCV on HIV. ${ }^{28} 29$

The large pool clotting factor used to treat these patients was obtained from donors in the UK and USA and thus the distribution of genotypes reflects the prevalent genotypes found in North Europe and North America (genotypes 1, 2, and 3). ${ }^{30}$ However, in haemophilic patients in the USA, $45 \%, 7 \%$, and $42 \%$ are reported to have genotypes 1,2 , and $3^{31}$ compared with $63 \%, 14 \%$, and $18 \%$, respectively in our cohort. The majority of these patients were exposed to many batches of clotting factor concentrate over a long period, each bottle being made from a donor pool of several thousand donors. It is not clear why a particular genotype becomes the dominant genotype in any one haemophilic patient. The prevalence of genotype 1 may reflect a less robust immune response at the time of infection with $\mathrm{HCV}$, and this in turn could explain the influence of genotype 1 in hastening the progression of both $\mathrm{HCV}$ and HIV; type 1 may have greater replication competence or may have been epidemiologically more prevalent prior to HIV infection.

We have shown that $9 \%$ of these haemophilic patients spontaneously cleared $\mathrm{HCV}$, as have others, ${ }^{32}$ and almost half of individuals infected with anti-D immunoglobulin..$^{33}{ }^{34}$ The majority of patients who cleared HCV had non-severe haemophilia and therefore infrequent treatment with clotting factor concentrate. Thus viral variants, including more virulent variants, to which they will have been exposed is likely to have been less. Patients who cleared the virus were young at first exposure and therefore it is possible that their immune response at the time of infection was more effective. Thus a report from Germany showed that many individuals who had acquired hepatitis $\mathrm{C}$ infection in childhood during cardiac surgery had spontaneously cleared the virus after 20 years. ${ }^{35}$ Of patients who became infected with HIV from clotting factor concentrates, most would also have been infected with $\mathrm{HCV}$, either at the same time or earlier. Thus it is remarkable that three individuals coinfected with HIV appar- 
ently cleared $\mathrm{HCV}$ with consistently negative $\mathrm{HCV}$ viraemia.

Two thirds of HIV negative patients who died in this study had increased alcohol consumption. Chronic alcoholism in patients with HCV appears to cause more severe and rapidly progressive liver disease, leading more frequently to cirrhosis of the liver and HCC. ${ }^{36}$ Excessive alcohol intake has been associated with increased HCV RNA levels as well as aminotransferase levels, although the mechanism is poorly understood. ${ }^{37} 38$

$\mathrm{HCV}$ infection is now recognised as a major risk factor for HCC and there seems to be an incubation period of two or three decades on average. $^{39}$ The four patients who died with HCC had been infected for two decades and this is likely to become more common in this group of patients who were infected from 1977 (median year).

One patient died only eight years after infection with $\mathrm{HCV}$ as a result of surgical bleeding after liver biopsy. ${ }^{13}$ It is largely as a result of this unfortunate experience that after an initial enthusiasm for liver biopsy ${ }^{40}$ we have chosen to manage this patient group conservatively relying on detailed clinical history, liver function tests, HCV genotype, viral load, and PCR, together with endoscopy and imaging to chart the natural history and monitor treatment for HCV. Thus data on cirrhosis are limited and include those for whom there was a rare biopsy performed in life or postmortem liver biopsy.

Clearly the challenge is to provide treatment to delay progression or "cure" these patients. Unfortunately, a large number have poor prognostic factors for successful eradication: male sex, high viral load, long period of infection, type 1 HCV, and HIV coinfection. Nevertheless, a minority of these patients responded to alpha interferon alone or combination therapy ${ }^{7-10}$ with response rates similar to those recently reported..$^{41}$

We thank Dr Vince Emery, Department of Virology and Dr Helen Devereux, Department of Retrovirology, Royal Free and University College Medical School, who gave helpful advice, the Department of Virology who performed the laboratory tests, and Ms Marie Johnson who prepared the manuscript. This work was undertaken by the Royal Free Hampstead NHS Trust who received a proportion of its funding from the NHS Executive: the views expressed in this publication are those of the author and not necessarily the views of the NHS Executive. Dr Thynn
Thynn Yee is supported by the MRC. Anja Griffioen is Thynn Yee is supported by the MRC. Anja Griffioen is No 262434

1 WHO. Hepatitis C: global prevalence. Wkly Epidemiol Rec 1997;72:341-4

2 Darby SC, Ewart DW, Giangrande PL, et al. Mortality from liver cancer and liver disease in haemophilic men and boys in UK given blood products contaminated with hepatitis C. in UK given blood product

3 Kernoff PB, Lee CA, Karayiannis P, et al. High risk of non-A non-B hepatitis after a first exposure to volunteer or commercial clotting factor concentrates: effects of prophylactic immune serum globulin. Br f Haematol 1985;60:469-79.

4 Telfer P, Sabin C, Devereux H, et al. The progression of $\mathrm{HCV}$-associated liver disease in a cohort haemophilic patients. Br f Haematol 1994;87:555-61.

5 Bennett E, Dormandy KM, Churchill WG, et al. Cryoprecipitate and the plastic blood-bag system: provision of adequate replacement therapy for routine treatment of haemophilia. BMF 1967;2:88-91.

6 Bolton-Maggs PH, Wensley RT, Kernoff PB, et al. Production and therapeutic use of a factor XI concentrate from plasma. Thromb Haemost 1992;67:314-19.

7 Lee CA, Kernoff PB, Karayiannis P, et al. Interferon therapy for chronic non-A, non-B and chronic delta liver disease in for chronic non-A, non-B and chronic delta
haemophilia. Br F Haematol 1989;72:235-8.
8 Telfer P, Devereux H, Colvin B, et al. Alpha interferon for hepatitis $\mathrm{C}$ virus infection in haemophiliac patients. hepatitis $C$ virus infection

9 Dusheiko G, Main J, Thomas H, et al. Ribavirin treatment for patients with chronic hepatitis C: results of a placebo-controlled study. F Hepatol 1996;25:591-8.

10 Bhagani S, Sabin C, Dean J, et al. Interferon-alpha-2B/ ribavirin combination therapy for chronic genotype $1 \mathrm{HCV}$ in haemophilic patients—early results. Haemophilia 1998;4: 262.

11 Lee CA, Phillips A, Elford J, et al. The natural history of human immunodeficiency virus infection in a haemophilic cohort. Br f Haematol 1989;73:228-34.

12 Lee CA, Kernoff PB, Karayiannis P, et al. Acute fulminant non-A, non-B hepatitis leading to chronic active hepatitis after treatment with cryoprecipitate. Gut 1985;26:639-41.

13 Lee CA. Investigation of chronic hepatitis C infection in individuals with haemophilia. Br f Haematol 1997;96:425-

14 Nitu IC, Lee CA, Dillon AP, et al. Management of liver failure in a haemophilic patient co-infected with HIV and HCV. Clin Lab Haematol 1999;21:139-41.

15 Schoeman MN, Liddle C, Bilous M, et al. Chronic non-A, non-B hepatitis: lack of correlation between biochemical and morphological activity and effects of immunosuppressive therapy on disease progression. Aust N Z F Med 1990; 20:56-62.

16 Martin P, Di Bisceglie AM, Kassianides C, et al. Rapidly progressive non-A, non-B hepatitis in patients with human immunodeficiency virus infection. Gastroenterology 1989; 7:1559-61

17 Eyster ME, Diamondstone LS, Lien JM, et al. Natural history of hepatitis $C$ virus infection in multitransfused haemophiliacs: effect of coinfection with human immunodeficiency virus. The Multicenter Haemophilia Cohort Study. F Acquir Immune Defic Syndr 1993;6:602-10.

18 Soto B, Sanchez-Quijano A, Rodrigo L, et al. Human immunodeficiency virus infection modifies the natural history of chronic parenterally-acquired hepatitis $\mathrm{C}$ with an unusually rapid progression to cirrhosis. F Hepatol 1997;26: unus.

19 Telfer PT, Brown D, Devereux H, et al. HCV RNA levels and HIV infection: evidence for a viral interaction in haemophilic patients. Br f Haematol 1994;88:397-9.

20 Eyster ME, Fried MW, Di Bisceglie AM, et al. Increasing hepatitis C virus RNA levels in hemophiliacs: relationship to human immunodeficiency virus infection and liver disease. Blood 1994;84:1020-3.

21 Gretch DR. Diagnostic tests for hepatitis C. Hepatology 1997;26(3 suppl 1):43-7S

22 Nguyen TT, Sedghi-Varizi A, Wilkes LB, et al. Fluctuations in viral load (HCV RNA) are relatively insignificant in untreated patients with chronic HIV infection. If Viral Hepat 1996;3:75-8.

23 Seeff LB. Natural history of hepatitis C. Hepatology 1997;26 (3 suppl 1):21-8S

24 Yamada G, Tanaka E, Muira T, et al. Epidemiology of genotypes of hepatitis $\mathrm{C}$ virus in Japanese patients with type C chronic liver diseases: a multi-institution analysis. $\mathcal{F}$ Gastroenterol Hepatol 1995;10:538-45.

25 Kobayashi M, Tanaka E, Sodeyama $T$, et al. The natural course of chronic hepatitis C: a comparison between patients with genotypes 1 and 2 hepatitis $C$ viruses. Hepatology 1996;23:695-9.

26 Dusheiko G, Schmilovitz-Weiss H, Brown D, et al. Hepatitis $\mathrm{C}$ virus genotypes: an investigation of type-specific differences in geographic origin and disease. Hepatology 1994;19:13-18.

27 Romeo R, Tommasini MA, Rumi MG, et al. Genotypes in the progression of hepatitis $\mathrm{C}$ related cirrhosis and development of hepatocellular carcinoma. Hepatology 996;24(4 suppl):153A

28 Sabin CA, Telfer P, Phillips AN, et al. The association between hepatitis $C$ virus genotype and human immunodeficiency virus disease progression in a cohort of hemophilic men. F Infect Dis 1997;175:164-8.

29 Hatzakis A, Touloumi G, Karafoulidou A, et al. Hepatitis C virus (HCV) genotypes and progression of HIV infection in hemophiliacs. 12th World AIDS Conference, Geneva; June 28-July 3 1998:147.

30 Jarvis LM, Ludlam CA, Simmonds P. Hepatitis C virus genotypes in multi-transfused individuals. Haemophilia 1995; (suppl 4):3-7.

31 Eyster ME, Sherman KE, Gredert JJ, et al. Prevalence and changes in hepatitis C virus genotype among multitrans1062-9.

32 Mauser-Bunschoten EP, Bresters D, van Drimmelen AA, et al. Hepatitis C infection and viremia in Dutch hemophilia patients. F Med Virol 1995;45:241-6.

33 Dittmann S, Roggendorf M, Durkop J, et al. Long-term persistence of hepatitis $\mathrm{C}$ virus antibodies in a single source outbreak. F Hepatol 1991;13:323-7.

34 Kenny-Walsh E. Clinical outcomes after hepatitis C infection from contaminate anti-D immune globulin. Irish Hepatology Research Group. N Engl f Med 1999;340: 1228-33.

35 Vogt M, Lang T, Frosner G, et al. Prevalence and clinical outcome of hepatitis $\mathrm{C}$ infection in children who underwent cardiac surgery before the implementation of blood-donor screening. N Engl f Med 1999;341:866-70.

36 Schiff ER. Hepatitis C and alcohol. Hepatology 1997; 26(suppl 1):39-42S 
37 Mendenhall CL, Seeff L, Diehl AM, et al. Antibodies to hepatitis $B$ virus and hepatitis $C$ virus in alcoholic hepatitis and cirrhosis: their preva
tology 1991;14:581-9.

38 Nology $1991 ; 14: 581-9$. titis $C$ virus antibodies and hepatitis $C$ virus RNA in patient with alcoholic liver disease. Hepatology 1991;14:985-9.

39 Di Bisceglie AM. Hepatitis C and hepatocellular carcinoma. Hepatology 1997;26(suppl 1):34-8S.

40 Bamber M, Murray A, Arborgh BA, et al. Short incubation non-A, non-B hepatitis transmitted by factor VIII concen- trates in patients with congenital coagulation disorders. Gut 1981;22:854-9.

41 Poynard T, Marcellin P, Lee SS, et al. Randomised trial of interferon $2 \mathrm{~b}$ plus ribavirin for 48 weeks or for 24 weeks versus interferon $2 \mathrm{~b}$ plus placebo for 48 weeks for treatment of chronic infection with hepatitis $\mathrm{C}$ virus. Lancet 1998;352:1426-32.

42 McHutchison JG, Gordon SC, Schiff ER, et al. Interferon alpha-2b alone or in combination with ribavirin as initial treatment for chronic hepatitis C. $N$ Engl f Med 1998;339: 1485-92.

\section{8th United European Gastroenterology Week}

The UEGW abstract book (Gut 2000;47(suppl III)) has again been produced as a CD-ROM and can be found attached to the inside back cover of this issue. 